\title{
Pentalysine $\beta$-Carbonylphthalocyanine Zinc: An Effective Tumor-Targeting Photosensitizer for Photodynamic Therapy
}

\author{
Zhuo Chen $[\mathrm{a}],[\mathrm{b}],+$, Shanyong Zhou ${ }^{[b],+}$, Jincan Chen ${ }^{[b]}$, Dr. Yicai Deng ${ }^{[c]}$, Zhipu Luo[a],[b], \\ Hongwei Chen ${ }^{[a],[b]}$, Prof. Michael R. Hamblin ${ }^{[\mathrm{d}],[\mathrm{e}],[\mathrm{f}]}$, and Prof. Mingdong Huang ${ }^{[\mathrm{a}],[\mathrm{b}]}$ \\ Mingdong Huang: mhuang@fjirsm.ac.cn \\ [a] Graduate University of Chinese Academy of Sciences, 19 Yuquan Road, Shijingshan District, \\ Beijing 100049 (China), Fax: (+86) 591-83714946 \\ [b] China-Denmark Center for Proteases and Cancer, State Key Laboratory of Structural \\ Chemistry, Division of Chemical Biology, Fujian Institute of Research on the Structure of Matter, \\ Chinese Academy of Sciences, 155 Yang Qiao West Road, Fuzhou, Fujian 350002 (China) \\ [c] Sun Yat-Sen University No. 1 Hospital, 58 Zhong Shan No. 2 Road, Guangzhou, Guangdong \\ 510080 (China) \\ [d] Wellman Center for Photomedicine, Massachusetts General Hospital, 40 Blossom Street, \\ Boston MA 02114 (USA) \\ [e] Department of Dermatology, Harvard Medical School, 55 Fruit Street, Boston, MA 02114 (USA) \\ [f] Harvard-MIT Division of Health Sciences and Technology, 77 Massachusetts Avenue, \\ Cambridge, MA 02139 (USA)
}

\section{Abstract}

Unsymmetrical phthalocyanine derivatives have been widely studied as photosensitizers for photodynamic therapy (PDT), targeting various tumor types. However, the preparation of unsymmetrical phthalocyanines is always a challenge due to the presence of many possible structural isomers. Herein we report a new unsymmetrical zinc phthalocyanine, pentalysine $\beta$ carbonylphthalocyanine zinc (ZnPc-(Lys)5), that was prepared in large quantity and high purity. This is a water-soluble cationic photosensitizer and maintains a high quantum yield of singlet oxygen generation similar to that of unsubstituted zinc phthalocyanine $(\mathrm{ZnPc})$. Compared with anionic $\mathrm{ZnPc}$ counterparts, ZnPc-(Lys)5 shows a higher level cellular uptake and 20-fold higher phototoxicity toward tumor cells. Pharmacokinetics and PDT studies of ZnPc-(Lys) $)_{5}$ in S180 tumor-bearing mice showed a high ratio of tumor versus skin retention and significant tumor inhibition. This new molecular framework will allow synthetic diversity in the number of lysine residues incorporated and will facilitate future QSAR studies.

\section{Keywords}

cancer; cytotoxicity; pharmacokinetics; photodynamic therapy; synthesis

Correspondence to: Mingdong Huang, mhuangefjirsm.ac.cn.

${ }^{+}$These authors contributed equally to this work.

Supporting information for this article is available on the WWW under http://dx.doi.org/10.1002/cmdc.201000042. 


\section{Introduction}

Photodynamic therapy (PDT) has received increasing attention as a promising approach in anticancer treatment.[1-3] Among the various photosensitizers, phthalocyanines (Pcs) have been widely studied owing to their advantageous photophysical properties: stronger absorption at $\lambda 670 \mathrm{~nm}$ (at which the depth of light penetration in tissue is twice that at $\lambda 630$ $\mathrm{nm}$ with porfimer sodium (Photofrin)), selective retention by tumor cells, insignificant toxicity, and high chemical and photochemical stability.[4,5] Nevertheless, unsubstituted Pcs are hydrophobic and insoluble in physiological solvents. It has been suggested by some experimental studies that amphiphilic photosensitizers are, in general, more photodynamically active than highly hydrophobic or highly hydrophilic molecules of similar type.[6,7] Peripheral sulfonation of the Pc ring is a well-documented method to increase the aqueous solubility of Pcs and thus their suitability for use in biological systems. Cauchon et al. found that functionalizing a zinc phthalocyanine $(\mathrm{ZnPc})$ with three sulfonate groups and one hexynyl hydrophobic substituent greatly enhances cellular uptake, with preferential localization at the mitochondrial membranes, leading to a photodynamic effect toward EMT-6 murine mammary tumor cells. [8] Disulfonated Pcs in which the two sulfonate groups are adjacent to each other were found to be more active than isomers bearing the two sulfonate groups at opposite ends of the molecule;[9] they penetrate the cell membrane effectively and show high photodynamic activity in both cultured cells and experimental animal tumors.[10-13] A recent example is zinc disulfo-

di(phthalimidomethyl)phthalocyanine $\left(\mathrm{ZnPc}-\mathrm{S}_{2} \mathrm{P}_{2}\right)$, which was shown to be effective at killing tumor cells in vitro[14,15] and causing tumor regression in vivo.[16] A phase I clinical trial for this amphipathic photosensitizer is currently underway.[17] Another disulfonated derivative, disulfonated aluminum phthalocyanine $\left(\mathrm{AlPcS}_{2}\right)$, has also been shown to induce tumor regression mainly through direct killing of tumor cells rather than damaging the tumor vasculature.[12,13]

Positively charged substituents are often introduced into the photosensitizer not only to increase the polarity and solubility of the hydrophobic phthalocyanine ring, but also to increase cellular uptake and to facilitate selective targeting to tumor cells and subcellular targeting to vulnerable intracellular sites. [18] Cationic pyridinium phthalocyanine zinc was observed to be more efficient in bacterial phototoxicity than the anionic or neutral ZnPcs. Additionally, positively charged Pcs such as $N$-methylpyridyloxyphthalocyanine and polyL-lysine-chlorin e6[19] have been found to be capable of efficiently photo-inactivating both Gram-negative and Gram-positive bacteria.

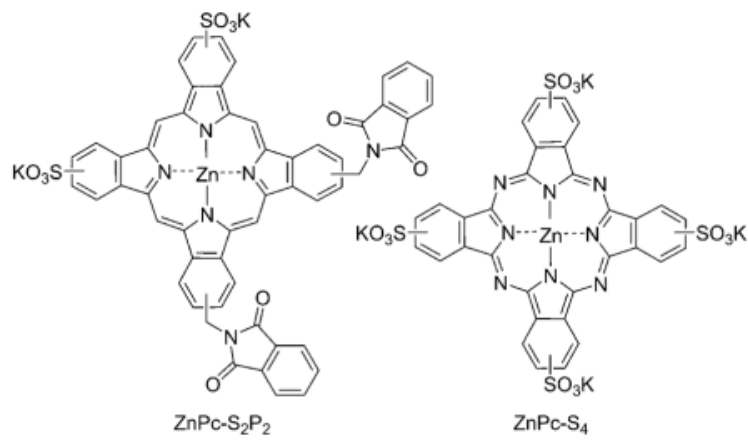

It is a major challenge to purify substituted Pcs into single isomeric products. This is especially true for asymmetrically substituted Pcs due to the presence of many possible structural isomers. We developed a synthesis and purification protocol that allows largescale preparation of monosubstituted $\beta$-carboxyphthalocyanine zinc.[20] Based on this compound, we synthesized an unsymmetrical ZnPc conjugate, pentalysine $\beta$ - 
carbonylphthalocyanine zinc (ZnPc-(Lys)5). The quantitative cellular uptake and phototoxicity of this conjugate were compared with two anionic $\mathrm{ZnPc}$ derivatives: $\mathrm{ZnPc}$ $\mathrm{S}_{2} \mathrm{P}_{2}$ and zinc phthalocyanine tetrasulfonate $\left(\mathrm{ZnPc}-\mathrm{S}_{4}\right)$. The photodynamic activities were evaluated in vitro in three cell lines (derived from human stomach adenocarcinoma, human chronic myeloid leukemia, and human embryo lung fibroblasts) and in vivo on S180 tumors implanted intradermally in Kunming mice. We also carried out pharmacokinetics and biodistribution studies on this ZnPc-polylysine conjugate. Our studies demonstrate that $\mathrm{ZnPc}$-(Lys) $)_{5}$ has favorable in vitro and in vivo photodynamic effects, and suggest that ZnPc(Lys) $)_{5}$ could be a valuable drug candidate for further preclinical development.

\section{Results and Discussion}

Phthalocyanines are potent photosensitizers for the PDT of cancer. Derivatization of Pcs has been commonly used to modulate their biological properties such as aqueous solubility and tumor targeting. However, the large-scale purification of substituted-and particularly unsymmetrical-Pcs into a single isomeric product is quite challenging. Herein we describe the development of a high-purity, water-soluble $\mathrm{ZnPc}$ photosensitizer: ZnPc-(Lys) 5 . The positively charged pentalysine group in the photosensitizer can provide selective targeting to tumors, as tumor cells have a greater net negative charge than normal cells, owing to the overexpression of poly(sialic acid) residues at tumor cell surfaces.[21] Moreover, positively charged species (especially higher-molecular-weight species) have much greater cell uptake than neutral or anionic molecules due to adsorptive endocytosis.[22]

\section{Properties of ZnPc-(Lys)}

ZnPc-(Lys) $)_{5}$ was prepared in high quantity and purified to $99 \%$ purity by reversed-phase HPLC (Figure 1). The structure of ZnPc-(Lys) 5 was confirmed by NMR spectroscopy and mass spectrometry (calculated for $\mathrm{C}_{63} \mathrm{H}_{76} \mathrm{~N}_{18} \mathrm{O}_{7} \mathrm{Zn} \mathrm{m} / z: 1262.80$, found: 1263.9). The UV/ Vis absorption spectrum of ZnPc-(Lys) $)_{5}$ in DMSO (Figure 1 inset) is typical for $\mathrm{ZnPc}$, with the strongest absorption at $\lambda 678 \mathrm{~nm}\left(\varepsilon=118380 \mathrm{~L} \mathrm{~mol}^{-1} \mathrm{~cm}^{-1}\right)$. The quantum yield for singlet oxygen photogeneration for $\mathrm{ZnPc}$-(Lys) $)_{5}$ in DMSO was determined to be 0.64 in current studies, which is similar to that for $\mathrm{ZnPc}(0.67),[23]$ and suggests that the addition of a pentalysine group does not significantly alter the generation of singlet oxygen.

\section{Cellular uptake of photosensitizers}

The cellular uptake of ZnPc-(Lys) 5 and two anionic ZnPcs were all dose dependent, with higher $\mathrm{ZnPc}$ concentrations leading to greater cellular uptake (Figure 2). ZnPc-(Lys) 5 had a much higher cellular uptake than the anionic ZnPcs in all three cell lines tested (BGC-823, $\mathrm{K} 562$, and HELF). This is likely due to the positive charges introduced by pentalysine. ZnPc-(Lys) 5 also shows greater uptake in tumor cells (BGC-823, shown in Figure 2a; the cellular uptake curve of K562 is similar to that of BGC-823) than in normal cells (HELF, shown in Figure $2 \mathrm{~b}$ ) over an incubation period of $2 \mathrm{~h}$. This enhanced cellular uptake by pentalysine conjugation could be due to ionic interactions between positively charged $\mathrm{ZnPc}$ (Lys) $)_{5}$ and the negatively charged tumor cell surfaces, which overexpress poly(sialic acid) residues.[21]

\section{Subcellular localization of photosensitizers}

Figure 2c shows that ZnPc-(Lys) $)_{5}(10 \mu \mathrm{M})$ is internalized by K562 cells after $2 \mathrm{~h}$ incubation. For anionic $\mathrm{ZnPc}_{-} \mathrm{S}_{2} \mathrm{P}_{2}$ or $\mathrm{ZnPc}-\mathrm{S}_{4}$, no significant accumulation was found inside the cells in this time frame. These findings are consistent with the higher cellular uptake of ZnPc-(Lys) discussed above. Subcellular localization of photosensitizers has been widely reported, and has been found to be dependent on the nature of both the photosensitizer and the peptide or ligand attached.[24] Lo et al. reported that a ZnPc singly substituted with a 1,3- 
bis(dimethylamino)-2-propoxy group localized to the cell membrane of human HT29 colorectal carcinoma cells after $2 \mathrm{~h}$ incubation.[25] However, symmetrical cationic 3pyridiloxy silicon phthalocyanines with two bulky axial groups attached to the central $\mathrm{Si}$ atom were found to localize preferentially within the lysosomes of human HEp2 cells after $24 \mathrm{~h}$ incubation.[22] A series of Pc-peptide conjugates bearing multiple cationic residues were found to localize preferentially within lysosomes.[26] Some PEG-substituted porphyrin derivatives[24,27] and several cationic porphyrins[28,29] were also reported to localize in lysosomes. Photosensitizers with anionic substituents, such as sulfonate or carboxylate groups, have been observed to localize preferentially in lysosomes and to relocate to the nucleus upon illumination,[30] whereas lipophilic photosensitizers functionalized with cationic groups were found to traverse the mitochondrial membrane and to preferentially accumulate in mitochondria,[31] the subcellular organelle widely demonstrated to be a key component in apoptosis, the preferred cell-death pathway in PDT. These diverse results suggest further systematic studies are required to understand the relationship between subcellular localization, cellular uptake kinetics, and the structures of Pc photosensitizers.

\section{Phototoxicity and dark toxicity of ZnPcs}

$\mathrm{ZnPc}-(\mathrm{Lys})_{5}$ exhibits greater phototoxicity than either $\mathrm{ZnPc}-\mathrm{S}_{2} \mathrm{P}_{2}$ or $\mathrm{ZnPc} \mathrm{S}_{4}$ at $2 \mathrm{~h}$ incubation with $\mathrm{K} 562$ cells (Figure 3a) in a dose-dependent manner, consistent with its higher cellular uptake. The concentrations required to yield $50 \%$ growth inhibition $\left(\mathrm{IC}_{50}\right)$ were determined to be $10 \mu \mathrm{M}$ for $\mathrm{ZnPc}-(\mathrm{Lys})_{5}$ and $>30 \mu \mathrm{M}$ for $\mathrm{ZnPc}-\mathrm{S}_{2} \mathrm{P}_{2}$ in $\mathrm{K} 562$ cells. This phototoxicity is dependent on incubation time, as increasing the exposure to $24 \mathrm{~h}$ dramatically lowers the $\mathrm{IC}_{50}$ values to 0.2 and $4.3 \mu \mathrm{M}$ for $\mathrm{ZnPc}-(\mathrm{Lys})_{5}$ and $\mathrm{ZnPc}-\mathrm{S}_{2} \mathrm{P}_{2}$, respectively (Figure $3 \mathrm{~b}$ ). For anionic $\mathrm{ZnPc}_{\mathrm{S}}$, the photodynamic effect is minimal, and the long incubation time does not increase phototoxicity toward K562 cells: no measurable difference in $\mathrm{IC}_{50}$ was observed for two different incubation times ( 2 or $24 \mathrm{~h}$; Figure 3b). Similar results were consistently observed with the adherent cells BGC-823. We also examined the phototoxicities of these photosensitizers toward a fibroblast cell line (HELF); $\mathrm{ZnPc}$-(Lys) $)_{5}$ is less toxic to HELF cells than to tumor cells (K562, Figure 3c). The $\mathrm{IC}_{50}$ value of ZnPc-(Lys) $)_{5}$ toward HELF cells was at least fivefold higher than that toward tumor cells (K562). This could be due to the slower uptake of ZnPc-(Lys) 5 by HELF cells than by tumor cells. Notably, $\mathrm{ZnPc}-\mathrm{S}_{2} \mathrm{P}_{2}$ showed similar selectivity of photodynamic effect on tumor cells and normal cells (Figure $3 \mathrm{~b}$ and $3 \mathrm{c}$ ), despite the fact that it showed a lower cellular uptake than $\mathrm{ZnPc}$-(Lys) 5 ; this suggests a different mechanism or different cellular localization underlying the photodynamic effect between these two $\mathrm{ZnPcs}$. For $\mathrm{ZnPc}-\mathrm{S}_{4}$, no phototoxicity was observed at the light dosage used $\left(1.5 \mathrm{~J} \mathrm{~cm}^{-2}\right)$ even after $24 \mathrm{~h}$ incubation (Figure 3c). This is consistent with published values; for example, an $\mathrm{IC}_{50}$ value of $\sim 200$ $\mu \mathrm{M}$ was recently reported for the photoinactivation of human SiHa cervical carcinoma cells. [32] In the absence of laser light, all compounds do not show significant cellular toxicity (Figure 3, right-hand side), suggesting a broad safety margin for these $\mathrm{ZnPc}$ photosensitizers. Taken together, these in vitro cellular results suggest that the positively charged $\mathrm{ZnPc}$-(Lys) 5 has a higher photodynamic efficiency than the anionic ZnPcs (either $\mathrm{ZnPc}-\mathrm{S}_{2} \mathrm{P}_{2}$ or $\left.\mathrm{ZnPc}-\mathrm{S}_{4}\right)$.

\section{Biodistribution studies with ZnPc-(Lys) 5}

Polylysine conjugation has been shown to be an effective delivery vehicle to enhance the antimicrobial activity of photosensitizers.[19,33] However, polylysine can be degraded in the circulatory system by trypsin-like serine proteases specific for positively charged residues such as arginine and lysine.[34] To evaluate the effect of this potential instability of polylysine on the biodistribution of $\mathrm{ZnPc}-(\mathrm{Lys})_{5}$, we investigated the plasma clearance of ZnPc-(Lys) 5 . The photosensitizer was administered intravenously in tumor-bearing mice at a 
dose of $2 \mathrm{~m} \mathrm{~kg}^{-1}$, and the amounts of photosensitizer present in the tissues or plasma were quantified by fluorescence spectroscopy. The plasma elimination rate constant of $\mathrm{ZnPc}-$ (Lys) $)_{5}$ was found to be $1.12 \mathrm{~h}^{-1}$ after fitting to a single-phase exponential decay (Figure 4), which corresponds to a half-life of $0.6 \mathrm{~h}$. In addition, concentrations of ZnPc-(Lys) $)_{5}$ in the tumor and organs were assessed in this study.

As shown in Figure 5, the retention of ZnPc-(Lys) 5 in brain was consistently the lowest $\left(<500 \mathrm{ngg}^{-1}\right)$ during the entire observation period upon a single administration at $2 \mathrm{mg} \mathrm{kg}^{-1}$ and among all tissue samples examined. This potentially suggests low neurotoxicity for $\mathrm{ZnPc}-(\mathrm{Lys})_{5}$. The retention of $\mathrm{ZnPc}-(\mathrm{Lys})_{5}$ by kidney, lung, and spleen were high, however, and increased gradually from $30 \mathrm{~min}$ to $6-12 \mathrm{~h}$ post-injection, after which it decreased (Figure 5). The retention of $\mathrm{ZnPc}-(\mathrm{Lys})_{5}$ by skin and muscle during the entire observation period ( $96 \mathrm{~h}$ ) upon a single administration at $2 \mathrm{mg} \mathrm{kg}^{-1}$ was low. Thus, despite the fact that this lysine-containing photosensitizer can be degraded in plasma, ZnPc-(Lys) ${ }_{5}$ can distribute to various tissues in the murine body.

The tumor-to-skin ratio of ZnPc-(Lys) $)_{5}$ content was maintained from 2:1 to 4:1 during the $96 \mathrm{~h}$ observation window. This persistent enrichment of $\mathrm{ZnPc}$-(Lys) $)_{5}$ in tumors may allow for repetitive photodynamic treatments. It has been reported that hydrophobic photosensitizers have tumor-to-normal-tissue ratios of up to $8: 1$, whereas the structurally similar hydrophilic photosensitizers exhibit a 2:1 ratio.[35] We observed that ZnPc-(Lys) has higher retention in the liver (Figure $5 b$ ). The retention was decreased to $20 \%$ of its peak value after $96 \mathrm{~h}$. Nevertheless, it was reported that the hepatic toxicity only became evident at $\mathrm{ZnPc}$ concentrations exceeding $30 \mu \mathrm{M}$ with human cultured hepatocytes in vitro,[36] indicating the relatively low toxicity of $\mathrm{ZnPc}$. Moreover, a repetitive-dose-toxicity study of ZnPc- $\mathrm{S}_{2} \mathrm{P}_{2}$ in beagle dogs showed no mortality and no physiological abnormality at doses of up to $4.5 \mathrm{mg} \mathrm{kg}^{-1}$, even though some hepatic spots were found in the $4.5 \mathrm{mg} \mathrm{kg}^{-1}$ group during histopathological examination.[37] These results again indicate the relatively low toxicity of $\mathrm{ZnPc}$ photosensitizers.

\section{PDT studies of ZnPc-(Lys) $)_{5}$ on an $\mathbf{S 1 8 0}$ tumor model}

Antitumor activities of ZnPc-(Lys) 5 against S180 tumor model implanted in Kunming mice were evaluated by growth-inhibition analysis. Tumor specimens in all animals were harvested. The differences in tumor weight between treatment and control groups, and among the treatment groups, were assessed by one-way ANOVA. Table 1 shows significant inhibition of tumor growth in all treated groups relative to untreated animals $(p<0.01)$. ZnPc-(Lys) 5 produced similar tumor growth inhibition at doses of 1 and $2 \mathrm{mg} \mathrm{kg}^{-1}$, indicating ZnPc-(Lys) 5 reached its maximum effect at $1 \mathrm{mg} \mathrm{kg}^{-1}$ in the $\mathrm{S} 180$ tumor model. This relatively low dosage required for $\mathrm{ZnPc}$-(Lys $)_{5}$ in vivo is in good agreement with its high rate of cellular uptake.

Interestingly, tumor-bearing mice treated only with laser light showed a partial inhibitory effect on their tumor growth. This could be ascribed to the possibility that the red light at $\lambda$ $680 \mathrm{~nm}$ may elicit immune reactions in tumor-bearing mice, although this low-intensity laser irradiation is still not an established therapeutic modality.[38,39] On the other hand, the group treated with $\mathrm{ZnPc}-(\mathrm{Lys})_{5}$ in the absence of laser light also exhibited a partial decrease in tumor weight. However, the group treated with $\mathrm{ZnPc}-(\mathrm{Lys})_{5}$ in the presence of laser light showed a significantly stronger inhibition, confirming ZnPc-(Lys) ${ }_{5}$ as an effective photosensitizer in in vivo PDT. 


\section{Conclusions}

We prepared a novel unsymmetrical zinc phthalocyanine-poly-lysine conjugate (ZnPc(Lys) $)_{5}$, which is water soluble and can be made in large quantity and high purity. Compared with two anionic $\mathrm{ZnPcs}\left(\mathrm{ZnPc}-\mathrm{S}_{4}\right.$ and $\left.\mathrm{ZnPc}-\mathrm{S}_{2} \mathrm{P}_{2}\right), \mathrm{ZnPc}-(\mathrm{Lys})_{5}$ showed a higher level of cellular uptake and $\sim 20$-fold higher phototoxicity toward tumor cells. Moreover, ZnPc(Lys) 5 showed about fivefold lower phototoxicity toward fibroblasts than toward tumor cells. Pharmacokinetics studies in S180 tumor-bearing mice showed that ZnPc-(Lys) 5 has high retention at tumor tissue, but low retention on skin and muscle and undergoes rapid clearance from plasma. PDT studies in S180 tumor-bearing mice showed that ZnPc-(Lys) 5 is quite effective at low dosage $\left(0.5 \mathrm{mg} \mathrm{kg}^{-1}\right)$, which is in good agreement with its rapid cellular uptake. Taken together, these results suggest that the water-soluble ZnPc-(Lys) $)_{5}$ is a highly promising photo-sensitizer for further development. This photosensitizer was used as a single compound without isomers, and was generated from monosubstituted $\beta$ carboxyphthalocyanine zinc.[20] This new molecular framework sets the foundation for future syntheses of an extensive series of $\mathrm{ZnPc}$ photosensitizers for further studies of structure-function relationships.

\section{Experimental Section}

\section{Preparation of $\mathrm{ZnPc}$ conjugates}

Monosubstituted $\beta$-carboxyphthalocyanine zinc $(\mathrm{ZnPc}-\mathrm{COOH}, \mathbf{5})$ was synthesized by statistical condensation of trimellitic anhydride $\mathbf{1}$ with phthalic anhydride $\mathbf{2}$ as described previously.[20] ZnPc-(Lys) (7) was then prepared by coupling 5 with $t$ Boc-protected pentalysine on Wang resin (Scheme 1). Typically, ZnPc-COOH (31.1 mg, $0.05 \mathrm{mmol}$ ) was dissolved in $N, N$-dimethylformamide (DMF, $31 \mathrm{~mL}$ ) with $5 \%$ pyridine, and was incubated with a peptide coupling agent $N, N^{\prime}$-dicyclohexylcarbodiimide (DCC, $20.6 \mathrm{mg}, 0.1 \mathrm{mmol}$ ) and an activating reagent 1-hydroxybenzotriazole (HOBt, $13.5 \mathrm{mg}, 0.1 \mathrm{mmol}$ ) for $30 \mathrm{~min}$ at room temperature. $t$ Boc-protected pentalysine (1 equiv) on Wang resin (Shanghai Biotech Bioscience and Technology Co. Ltd., Shanghai, China) was added to the solution, which was stirred overnight at room temperature to allow the reaction to reach completion. The Wang resin was washed with DMF and dried under vacuum. To cleave the coupled product from the resin and to cleave $t$ Boc protecting groups from lysine residues, the resin was allowed to react with $95 \%$ trifluoroacetic acid for $3 \mathrm{~h}$. Product 7 was precipitated by adding $\mathrm{CH}_{2} \mathrm{Cl}_{2}$, extracted with $\mathrm{CH}_{3} \mathrm{OH}$, and dried under vacuum. It was further purified by preparative HPLC (Dalian Elite Analytical Instruments Co. Ltd., Dalian, China) with a Fuji $\mathrm{C}_{18}$ column $(250 \times 30 \mathrm{~mm}, 10 \mu \mathrm{m}$, Beijing Chuangxin Tongheng Science \& Technology Co. Ltd., Beijing, China), eluting with a linear gradient of $50 \rightarrow 100 \%$ mixed solvent $\mathrm{CH}_{3} \mathrm{OH} /$ $\mathrm{CH}_{3} \mathrm{CN}(1: 1 \mathrm{v} / \mathrm{v})$. The final product 7 has a purity of $99 \%$, and the final yield is $33.8 \%$ based on compound 5 ( $\mathrm{ZnPc}-\mathrm{COOH})$. $\mathrm{ZnPc}-\mathrm{S}_{2} \mathrm{P}_{2}$ and $\mathrm{ZnPc}-\mathrm{S}_{4}$ were kindly provided by Prof. Naisheng Chen of Fuzhou University, China. $\mathrm{ZnPc}^{-\mathrm{S}_{4}}$ is water soluble, and was dissolved in phosphate-buffered saline (PBS). $\mathrm{ZnPc}-\mathrm{S}_{2} \mathrm{P}_{2}$ was dissolved in a solution of Cremophor EL $(2 \% v / v)$, propylene glycol $(20 \% \mathrm{v} / \mathrm{v})$, and $\mathrm{NaCl}(0.9 \% \mathrm{w} / \mathrm{w})$ and was stored in the dark at 4 ${ }^{\circ} \mathrm{C}$.

\section{Characterization of ZnPc-(Lys) ${ }_{5}$}

ZnPc-(Lys) 5 (7) was characterized by ${ }^{1} \mathrm{H}$ NMR (Bruker AV-400, $\left.400 \mathrm{MHz},\left[\mathrm{D}_{6}\right] \mathrm{DMSO}\right): \delta$ $=9.699(\mathrm{~s}, 1 \mathrm{H}), 7.816-9.311(\mathrm{~m}, 30 \mathrm{H}), 4.027-4.902(\mathrm{~m}, 5 \mathrm{H}), 2.787-2.926(\mathrm{~m}, 10 \mathrm{H}), 1.078-$ $2.122 \mathrm{ppm}(\mathrm{m}, 30 \mathrm{H}) ;{ }^{13} \mathrm{C}$ NMR (75 MHz, [D 6 ]DMSO): $\delta=174.183$ (-COOH, 1C), $172.693-$ 167.597 (-CO-, 5 C), 159.191-151.866 (-N-C=N-, 8C), 139.996-116.156 (Ar-C, 24C), 54.512-52.928 (-CH-, 5 C), 39.267-22.509 ppm (- $\mathrm{CH}_{2^{-}}$, 20C); FTIR (Magna-IR 750, Nicolett, KBr): $v=3400,3273,3058,2945,1677,1539,1486,1333,1203,1134,1089,754$, 
$724 \mathrm{~cm}^{-1}$; ESI HRMS (DECAX-30000 LCQ Deca XP): $\mathrm{m} / z[M+\mathrm{H}]^{+}$calcd for $\mathrm{C}_{63} \mathrm{H}_{76} \mathrm{~N}_{18} \mathrm{O}_{7} \mathrm{Zn}: 1263.8$, found: $1263.6, \mathrm{~m} / z[M+2 \mathrm{H}]^{2+}$ calcd for $\mathrm{C}_{63} \mathrm{H}_{76} \mathrm{~N}_{18} \mathrm{O}_{7} \mathrm{Zn}: 632.4$, found: 632.1). All results confirm the molecular structure of 7. The UV/Vis absorption spectrum of ZnPc-(Lys) 5 in DMF was recorded from $\lambda 300$ to $800 \mathrm{~nm}$ using quartz cuvettes with $1 \mathrm{~cm}$ path length on a Lambda-35 UV/Vis spectrometer (PerkinElmer, Massachusetts, USA) in DMSO $\left[\lambda_{\max }(\varepsilon)=678 \mathrm{~nm}\left(118380 \mathrm{Lmol}^{-1} \mathrm{~cm}^{-1}\right)\right]$. Analytical HPLC was carried out on a $\mathrm{C}_{18}$ RP HPLC system (Dalian Elite Analytical Instruments Co. Ltd., Dalian, China; column: SinoChrom ODS-BP, $250 \times 4.6 \mathrm{~mm}, 5 \mu \mathrm{m}$ ) using a linear gradient of $50 \rightarrow 100 \%$ $\mathrm{CH}_{3} \mathrm{OH} / \mathrm{CH}_{3} \mathrm{CN}(1: 1 \mathrm{v} / v)$ at a flow rate of $1 \mathrm{mLmin}^{-1}$.

\section{Singlet oxygen quantum yield determination}

Singlet oxygen $\left({ }^{1} \mathrm{O}_{2}\right)$ is believed to be the major cytotoxic agent involved in PDT. The quantum yield of ${ }^{1} \mathrm{O}_{2}$ generation by $\mathrm{ZnPc}$-(Lys) $)_{5}$ was measured with $\mathrm{ZnPc}$ as reference, which has a quantum yield of 0.67 in DMSO.[23] In our experiments, DMSO solutions containing $1 \mu \mathrm{M} \mathrm{ZnPc-(Lys)}$ ) and $30 \mu \mathrm{M}$ 1,3-diphenylisobenzofuran (DPBF, a scavenger molecule that is highly specific for ${ }^{1} \mathrm{O}_{2}$ ) were prepared in the dark; $2.0 \mathrm{~mL}$ of this DMSO solution was placed in a spectro-photometric cell of $1 \mathrm{~cm}$ path length and illuminated with $\lambda$ $670 \mathrm{~nm}$ laser light at $80 \mathrm{~mW} \mathrm{~cm}^{-2}$ in the presence of air (without degassing). The decay of DPBF absorbance at $\lambda 417 \mathrm{~nm}$ was followed every $5 \mathrm{~s}$. The concentration of DPBF was kept $<30 \times 10^{-5} \mathrm{M}$ to avoid chain reactions induced by DPBF in the presence of ${ }^{1} \mathrm{O}_{2}$.[40] These conditions resulted in first-order kinetics.[41] The ${ }^{1} \mathrm{O}_{2}$ quantum yield of $\mathrm{ZnPc}-(\mathrm{Lys})_{5}\left(\Phi_{\Delta}\right)$ was calculated with the following equation:[41]

$$
\Phi_{\Delta}=\Phi_{\Delta}^{Z n P c}\left(W \times I_{a b s}^{Z n P c}\right) /\left(W^{Z n P c} \times I_{a b s}\right)
$$

in which $\Phi_{\Delta}^{Z n P c}$ is the ${ }^{1} \mathrm{O}_{2}$ quantum yield for $\mathrm{ZnPc}$ in DMSO (0.67),[23] and $W$ and $W^{Z n P c}$ are the DPBF photobleaching rates for $\mathrm{ZnPc}$-(Lys) $)_{5}$ and $\mathrm{ZnPc}$, respectively. $I_{a b s}$ and $I_{a b s}^{Z n P c}$ are the respective light absorbance values for $\mathrm{ZnPc}-(\mathrm{Lys})_{5}$ and $\mathrm{ZnPc}$. The initial DPBF concentrations were kept the same for the $\mathrm{ZnPc}$ reference and the samples. The quantum yields were measured at least three times and were found to have a relative error of $\sim 10 \%$.

\section{Cell culture}

The cell lines used in these studies were human stomach adenocarcinoma cells (BGC-823), human chronic myeloid leukemia cells (K562), and human embryo lung fibroblasts (HELF). Related information can be found in the Supporting Information. All cell lines were purchased from the Shanghai Institute of Cell Biology, Chinese Academy of Sciences, China, and were routinely maintained in RPMI-1640 (GIBCO BRL), supplemented with $10 \%(v / v)$ heat-inactivated fetal calf serum (FCS), penicillin $\left(100 \mathrm{U} \mathrm{mL}^{-1}\right)$, and streptomycin $\left(100 \mu \mathrm{g} \mathrm{mL}^{-1}\right)$ at $37^{\circ} \mathrm{C}$ under humidified air containing $5 \% \mathrm{CO}_{2}$. The viability of cells was determined by Trypan blue dye exclusion. Cells were maintained in logarithmic phase with viability $>95 \%$. BGC-823 cells and HELF cells are adherent cells and thus need to be detached by treatment with a trypsin-EDTA solution before cell counting and dilution to 96 -well plates in preparation for photodynamic assays.

\section{Cellular uptake of photosensitizers}

Aliquots of cells $\left(\sim 10^{6}\right.$ per $1 \mathrm{~mL}$ growth medium) were incubated in 24-multiwell plates (Falcon) with the photosensitizers at various concentrations $\left(10^{-7}, 10^{-6.5}, 10^{-6}, 10^{-5.5}\right.$ and $10^{-5} \mathrm{M}$ ) for $2 \mathrm{~h}$ at $37^{\circ} \mathrm{C}$. The exponentially growing cells were then washed with sterile PBS before lysis with $\mathrm{NaOH}(0.1 \mathrm{~N}, 1.0 \mathrm{~mL}$ with $1 \% \mathrm{SDS})$ to give a homogenous solution. The 
fluorescence of the cell extract was measured on a Cary Eclipse fluorescence spectrophotometer (Varian Inc., Walnut Creek, CA, USA). The concentration of cellular protein was determined by the method of Lowry et al.[42] Standard curves were made with cell lysates treated as above with known added amounts of bovine serum albumin. Results are expressed as $\mu \mathrm{mol}$ phthalocyanine per $\mathrm{mg}$ cell protein.

\section{Subcellular localization of photosensitizers}

Cell suspensions $\left(\sim 1 \times 10^{5}\right.$ cells per $\left.1 \mathrm{~mL}\right)$ were plated onto glass cover slips and incubated for $18-24 \mathrm{~h}$ at $37^{\circ} \mathrm{C}, 5 \% \mathrm{CO}_{2}$ to allow cell adhesion. The medium was removed, and the attached cells were rinsed twice with PBS, and then overlaid with $1 \mathrm{~mL}$ culture medium containing $1 \%$ fetal bovine serum (FBS) and $1 \mu \mathrm{M}$ photosensitizer. After 2 or $24 \mathrm{~h}$ at $37^{\circ} \mathrm{C}$, the cells were washed twice with PBS to remove the unbound dye and then twice more with low-phosphate buffer (HBSS/HEPES). The cells were mounted for direct microscopic observation at $28^{\circ} \mathrm{C}$ and were examined with a laser scanning confocal microscope coupled to an inverted microscope with a $60 \times$ differential interference contrast oil immersion objective lens (Leica TCS SP5 microscope with a Bio-Rad Radiance 2000 confocal accessory). Specimens were excited by He-Ne laser light $(\lambda 633 \mathrm{~nm})$, and the emitted fluorescence was filtered using a barrier filter $(670 / 40 \mathrm{~nm}$ band pass). Optical sections were collected at $0.5 \mu \mathrm{m}$ intervals with a $2.2 \mathrm{~mm}$ pinhole aperture (i.e., a minimal opening in order to yield a maximal confocal component). Digitized images of 512×512 pixels were obtained with a pixel size of $0.34 \mu \mathrm{m}$. Laser line intensity, photometric gain, PMT setting, and filter attenuation were kept constant throughout the experiments.

\section{Phototoxicity and dark toxicity of photosensitizers}

Cells at a density of $1.5 \times 10^{5}$ cells per $\mathrm{mL}$ at a volume of $100 \mu \mathrm{L}$ per well were placed in 96multiwell plates and incubated over-night at $37{ }^{\circ} \mathrm{C}$ under $5 \% \mathrm{CO}_{2}$. One column of wells did not receive cells to serve as a blank. The cells were incubated with photosensitizers at various concentrations $\left(10^{-7}, 10^{-6.5}, 10^{-6}, 10^{-5.5}, 10^{-5}\right.$ and $\left.10^{-4.5} \mathrm{M}\right)$ for a period of 2 or $24 \mathrm{~h}$. One control column in the plate was filled with photosensitizer-free culture medium. The cells were then washed twice with sterile PBS before fresh medium was added. The plates were illuminated with a light dosage of $1.5 \mathrm{~J} \mathrm{~cm}^{-2}$ using a $670 \mathrm{~nm}$ SAS-DL3 medical laser (Beijing Shou'anshan Electronic Technology Co. Ltd., Beijing, China) and then returned to the incubator; dark toxicity was measured in parallel. The cells were irradiated as above by laser beam at a fluence of $12.5 \mathrm{~mW} \mathrm{~cm}^{-2}$ for $0-120$ seconds, giving a light dosage of $0-1.5 \mathrm{~J} \mathrm{~cm}^{-2}$. After $24 \mathrm{~h}$ incubation, cell viability was measured on a microplate reader (Synergy 4, BioTek Instruments) using the AlamarBlue fluorimetric cell viability assay (BioSource International Inc., Camarillo, CA, USA) with $\lambda_{\mathrm{ex}} 530 \mathrm{~nm}$ and $\lambda_{\mathrm{em}} 590 \mathrm{~nm}$. The average fluorescence reading of the blank wells was subtracted from the readings of the wells containing cells. Four replicates were run per drug dose and cell line, and each experiment was repeated three times. The cell phototoxicity curves were plotted as a function of photosensitizer dose, and $\mathrm{IC}_{50}$ values were calculated.

\section{Ascitic sarcoma-180 (S180) model}

Kunming mice (purchased from Shanghai SLAC Laboratory Animal Co. Ltd., Shanghai, China) were maintained and handled in accordance with the recommendations of the institutional animal care and use committee (IACUC). The animals were allowed free access to water and food throughout the course of the experiments. The S180 mouse sarcoma cells were supplied by the Shanghai Institute of Cell Biology, Chinese Academy of Sciences, China, and passaged weekly through Kunming mice with a body weight of 18-22 $\mathrm{g}$ in the form of ascites. To establish the mouse S180 tumor model, ascites containing S180 mouse sarcoma cells were harvested from the peritoneal cavity of a tumor-bearing mouse 5-7 days after inoculation, diluted with sterilized saline at a ratio of 1:6 (cell concentration was 
adjusted to $1.0 \times 10^{7} \mathrm{~mL}^{-1}$ ), and $0.2 \mathrm{~mL}$ aliquots were subcutaneously inoculated into the right armpit region of Kunming mice (18-22 g). Before inoculation, hair surrounding the tumor site was removed by shaving and application of chemical depilating cream (Shibi, Shanghai, China). The experiment was begun when the tumor diameter and thickness reached $4-8 \mathrm{~mm}$ and $2-4 \mathrm{~mm}$ respectively, typically $5-7$ days after inoculation.

\section{Biodistribution studies on $\mathrm{ZnPc}-(\text { Lys })_{5}$}

Tumor-bearing mice (prepared as above) were injected intravenously (i.v.) via the caudal vein with $\mathrm{ZnPc}$-(Lys) $)_{5}$ at $2.0 \mathrm{mg} \mathrm{kg}^{-1}(0.1 \mathrm{~mL}$ per $10 \mathrm{~g}$ body weight). At various time intervals after administration $(0.5 \mathrm{~min}$ to $120 \mathrm{~h})$, the animal blood was collected (five animals per time interval), after which the animals were sacrificed. The blood was centrifuged in Eppendorf tubes for $5 \mathrm{~min}$ at $2000 \mathrm{~g}$, and the plasma was collected. Organs and tissues of interest were removed, washed with saline $(0.9 \%)$, and blotted dry on a filter paper and weighed. Whole tumors, aliquots of other organs, and minced skin were homogenized in a 25 -fold volume of $1 \% \mathrm{NaOH}$ with $1 \%$ SDS. The homogenates were centrifuged at $4^{\circ} \mathrm{C}(1700 \mathrm{~g}$ for $20 \mathrm{~min})$. The photosensitizer concentration in the clear supernatant was assayed by the fluorescence of $\mathrm{ZnPc}-(\mathrm{Lys})_{5}$ in a Cary Eclipse fluorescence spectrophotometer (Varian Inc., Walnut Creek, CA, USA) $\left(\lambda_{\mathrm{ex}}=610 \mathrm{~nm}, \lambda_{\mathrm{em}}=680 \mathrm{~nm}\right.$; band pass: $5 \mathrm{~nm}$ ). Calibration curves were established by adding known amounts of photosensitizer to $100 \mu \mathrm{L}$ plasma or $100-500 \mathrm{mg}$ of tissue samples from control mice, after which the tissues were treated as described above.

\section{PDT studies of ZnPc-(Lys) 5}

Experimental tumor treatment was performed using photosensitizer in combination with laser light. The tumor-bearing mice were divided into a control group, and groups to be treated with ZnPc-(Lys) 5 alone, laser light alone, laser light plus ZnPc-(Lys) $)_{5}$, and laser light plus $\mathrm{ZnPc}-\mathrm{S}_{2} \mathrm{P}_{2}$ as the positive control group. Each group contained seven mice. For the $\mathrm{ZnPc}$ groups, ZnPc-(Lys) $)_{5}$ was injected into the mice through the caudal vein. For light treatment, the mice were anesthetized with sodium pentobarbital $\left(50 \mathrm{mg} \mathrm{kg}^{-1}\right)$ intraperitoneally. To minimize interference from hair at the tumor surface, tumor regions were shaved prior to light applications using an animal shaver, treated with depilatory cream, washed with liquid soap, and rinsed. Then, the center of the tumor was illuminated with laser light $\left(\lambda 670 \mathrm{~nm}, 217 \mathrm{~mW} \mathrm{~cm}{ }^{-2}\right.$ for $5 \mathrm{~min}$ for a total fluence of $\left.65 \mathrm{Jcm}^{-2}\right) 12 \mathrm{~h}$ after injection.

The antitumor activity of ZnPc-(Lys) 5 against S180 tumor models implanted in Kunming mice was evaluated by growth inhibition analysis. Tumor specimens in all animals were harvested in this study. The difference in tumor weight between treatment and control groups, and among the treatment groups, was assessed by one-way ANOVA.

\section{Statistics}

Statistical computations were performed using GraphPad Prism, v. 4.0 (GraphPad Software Inc., San Diego, CA, USA). Quantitative data were expressed as the mean \pm SEM from at least three independent experiments and assessed using one-way ANOVA and NewmanKeuls tests. A probability value of $p<0.05$ was considered statistically significant. Kinetics analyses and curve fitting were performed by GraphPad Prism software.

\section{Acknowledgments}

We gratefully acknowledge financial support of our research by FJIRSM (SZD08003, 2009I0029), the Natural Science Foundation (30973567, 30625011, and 30811130467), and the Chinese Ministry of Science and Technology (2006AA02A313). 


\section{Abbreviations}

$\begin{array}{ll}\text { PDT } & \text { photodynamic therapy } \\ \text { ZnPc } & \text { zinc phthalocyanine } \\ \text { ZnPc-(Lys) } & \text { pentalysine } \beta \text {-carbonylphthalocyanine zinc } \\ \text { ZnPc-S }_{\mathbf{2}} \mathbf{P}_{\mathbf{2}} & \text { zinc disulfo-di(phthalimidomethyl)phthalocyanine } \\ \text { ZnPc-S }_{\mathbf{4}} & \text { zinc phthalocyanine tetrasulfonate }\end{array}$

\section{References}

1. Hamblin, MR.; Mroz, P., editors. Advances in Photodynamic Therapy: Basic, Translational and Clinical. Artech House; Norwood: 2008.

2. Brown SB, Brown EA, Walker I. Lancet Oncol. 2004; 5:497-508. [PubMed: 15288239]

3. Dolmans DE, Fukumura D, Jain RK. Nat Rev Cancer. 2003; 3:380-387. [PubMed: 12724736]

4. Allen CM, Sharman WM, van Lier JE. J Porphyrins Phthalocyanines. 2001; 05:161-169.

5. van Lier, JE.; Spikes, JD. Ciba Foundation Symposium 146 - Photosensitizing Compounds: Their Chemistry, Biology and Clinical Use. Bock, G.; Harnett, S., editors. Wiley; Chichester: 1989.

6. Henderson BW, Bellnier DA, Greco WR, Sharma A, Pandey RK, Vaughan LA, Weishaupt KR, Dougherty TJ. Cancer Res. 1997; 57:4000-4007. [PubMed: 9307285]

7. Margaron P, Gregoire MJ, Scasnar V, Ali H, van Lier JE. Photochem Photobiol. 1996; 63:217-223. [PubMed: 8657735]

8. Cauchon N, Tian H, Langlois R, La Madeleine C, Martin S, Ali H, Hunting D, van Lier JE. Bioconjugate Chem. 2005; 16:80-89.

9. Peng Q, Moan J, Nesland JM, Rimington C. Int J Cancer. 1990; 46:719-726. [PubMed: 2210887]

10. Paquette B, Ali H, Langlois R, van Lier JE. Photochem Photobiol. 1988; 47:215-220. [PubMed: 3344290]

11. Brasseur N, Ali H, Langlois R, van Lier JE. Photochem Photobiol. 1988; 47:705-711. [PubMed: 3406131]

12. Margaron P, Madarnas P, Quellet R, van Lier JE. Anticancer Res. 1996; 16:613-620. [PubMed: 8687105]

13. Chan WS, Brasseur N, La Madeleine C, van Lier JE. Anticancer Res. 1996; 16:1887-1892. [PubMed: 8712717]

14. Huang HF, Chen YZ, Wu Y. Acta Pharmacol Sin. 2005; 26:1138-1144. [PubMed: 16115383]

15. Huang HF, Chen YZ, Wu Y. Acta Biochim Biophys Sin. 2005; 37:488-494. [PubMed: 15999210]

16. Huang J, Chen N, Huang J, Liu E, Xue J, Yang S, Huang Z, Sun J. Sci China Ser B: Chem. 2001; 44:113-122.

17. Huang Z. Photodiagn Photodyn Ther. 2008; 5:285-287.

18. Ball DJ, Wood SR, Vernon DI, Griffiths J, Dubbelman TM, Brown SB. J Photochem Photobiol B. 1998; 45:28-35. [PubMed: 9819897]

19. Soukos NS, Ximenez-Fyvie LA, Hamblin MR, Socransky SS, Hasan T. Antimicrob Agents Chemother. 1998; 42:2595-2601. [PubMed: 9756761]

20. Chen J, Chen N, Huang J, Wang J, Huang M. Inorg Chem Commun. 2006; 9:313-315.

21. Kornguth SE, Kalinke T, Robins HI, Cohen JD, Turski P. Cancer Res. 1989; 49:6390-6395. [PubMed: 2804985]

22. Li H, Jensen TJ, Fronczek FR, Vicente MG. J Med Chem. 2008; 51:502-511. [PubMed: 18189349]

23. Kuznetsova NA, Gretsova NS, Kalmykova EA, Makarova EA, Dashkevich SN, Negrimovskii VM, Kaliya OL, Luk'yanets EA. Russ J Gen Chem. 2000; 70:133-140.

24. Sibrian-Vazquez M, Jensen TJ, Hammer RP, Vicente MG. J Med Chem. 2006; 49:1364-1372. [PubMed: 16480271] 
25. Lo PC, Zhao B, Duan W, Fong WP, Ko WH, Ng DK. Bioorg Med Chem Lett. 2007; 17:10731077. [PubMed: 17127058]

26. Sibrian-Vazquez M, Ortiz J, Nesterova IV, Fernandez-Lazaro F, Sastre-Santos A, Soper SA, Vicente MG. Bioconjugate Chem. 2007; 18:410-420.

27. Sibrian-Vazquez M, Jensen TJ, Vicente MG. J Photochem Photobiol B. 2007; 86:9-21. [PubMed: 16987669]

28. Kessel D, Luguya R, Vicente MG. Photochem Photobiol. 2003; 78:431-435. [PubMed: 14653572]

29. Ricchelli F, Franchi L, Miotto G, Borsetto L, Gobbo S, Nikolov P, Bommer JC, Reddi E. Int J Biochem Cell Biol. 2005; 37:306-319. [PubMed: 15474977]

30. Patito IA, Rothmann C, Malik Z. Biol Cell. 2001; 93:285-291. [PubMed: 11770842]

31. Dummin H, Cernay T, Zimmermann HW. J Photochem Photobiol B. 1997; 37:219-229. [PubMed: 9085567]

32. Haywood-Small SL, Vernon DI, Griffiths J, Schofield J, Brown SB. Biochem Biophys Res Commun. 2006; 339:569-576. [PubMed: 16300726]

33. Hamblin MR, O’Donnell DA, Murthy N, Rajagopalan K, Michaud N, Sherwood ME, Hasan T. J Antimicrob Chemother. 2002; 49:941-951. [PubMed: 12039886]

34. Tegos GP, Anbe M, Yang C, Demidova TN, Satti M, Mroz P, Janjua S, Gad F, Hamblin MR. Antimicrob Agents Chemother. 2006; 50:1402-1410. [PubMed: 16569858]

35. Rück A, Steiner R. Minim Invasive Ther Allied Technol. 1998; 7:503-509.

36. Larroque C, Pelegrin A, van Lier JE. Br J Cancer. 1996; 74:1886-1890. [PubMed: 8980386]

37. Liu W, Chen N, Jin H, Huang J, Wei J, Bao J, Li C, Liu Y, Li X, Wang A. Regul Toxicol Pharmacol. 2007; 47:221-231. [PubMed: 17367655]

38. Schindl A, Schindl M, Pernerstorfer-Schçn H, Schindl L. J Invest Med. 2000; 48:312-326.

39. Basford JR. Lasers Surg Med. 1995; 16:331-342. [PubMed: 7651054]

40. Spiller W, Kliesch H, Wçhrle D, Hackbarth S, Rçder B, Schnurpfeil G. J Porphyrins Phthalocyanines. 1998; 2:145-158.

41. Maree S, Nyokong T. J Porphyrins Phthalocyanines. 2001; 5:782-792.

42. Lowry OH, Rosebrough NJ, Farr AL, Randall RJ. J Biol Chem. 1951; 193:265-275. [PubMed: 14907713] 


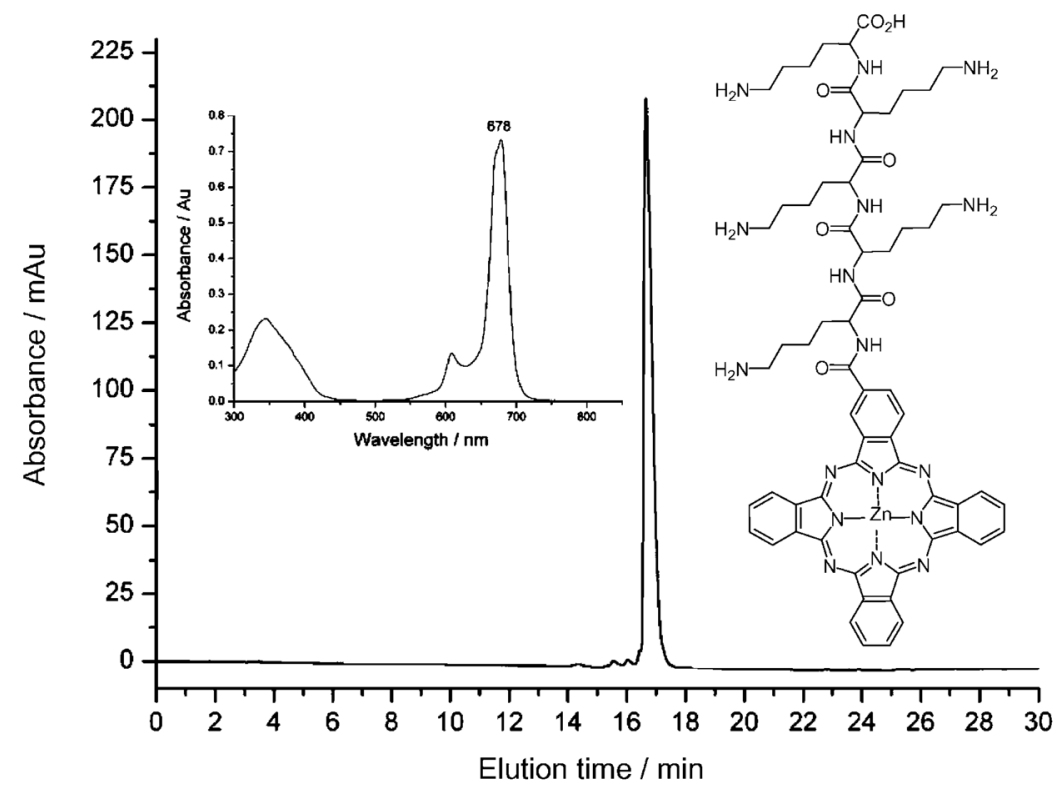

Figure 1.

The $\mathrm{C}_{18}$ reversed-phase HPLC chromatogram of ZnPc-(Lys) 5 (structure shown) and the UV/ Vis absorption spectrum in DMSO (inset). 

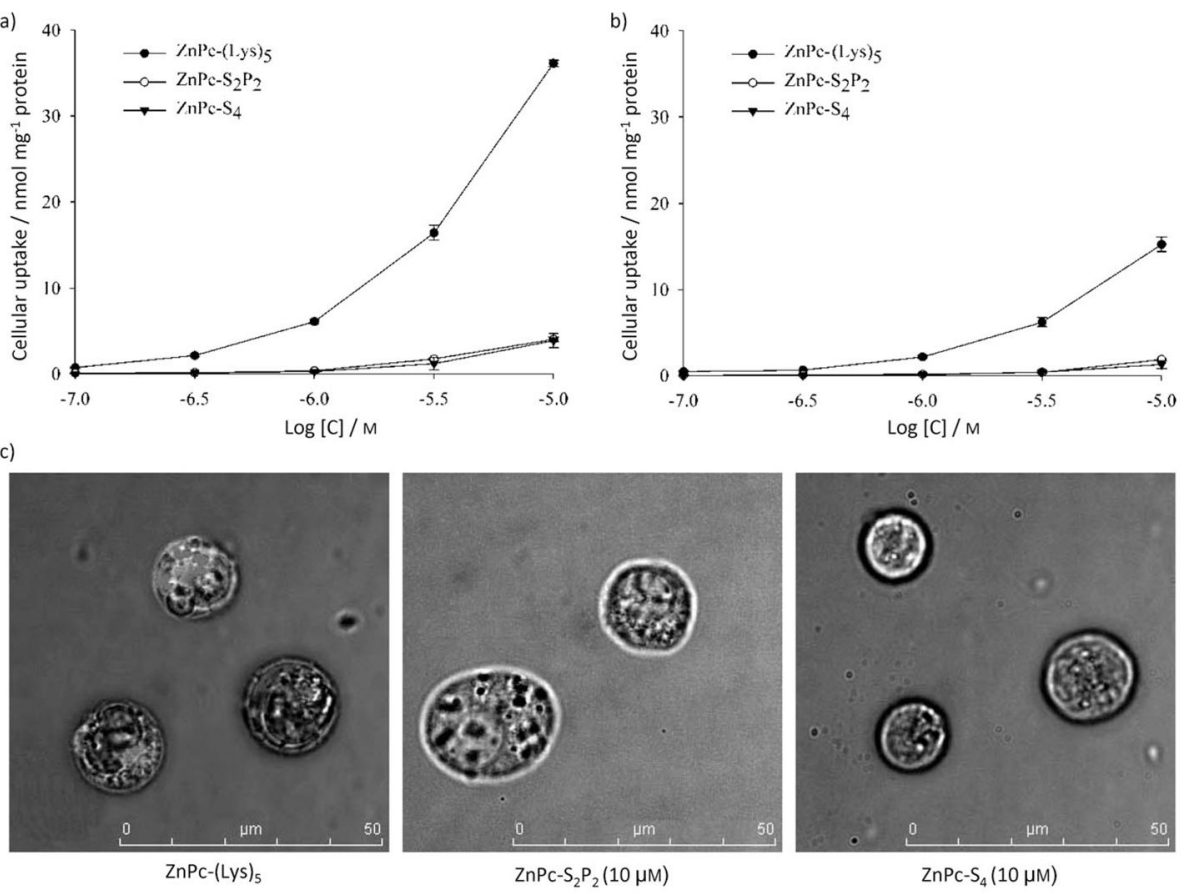

Figure 2.

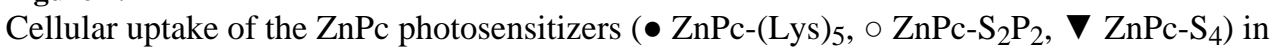
a) BGC-823 cells and b) HELF cells after $2 \mathrm{~h}$ incubation with each photosensitizer at various concentrations. Values represent the mean of three separate experiments; bars represent standard error of the mean (SEM). c) The internalization of $\mathrm{ZnPc}$ photosensitizers by K562 cells after $2 \mathrm{~h}$ incubation. 

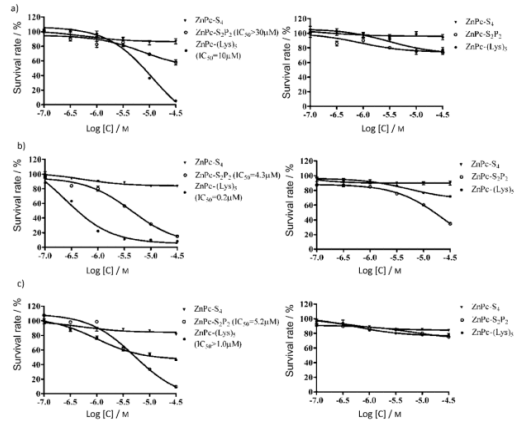

Figure 3.

Phototoxicity (light dosage: $1.5 \mathrm{~J} \mathrm{~cm}^{-2}$ at $\lambda 670 \mathrm{~nm}$, left) and dark toxicity (right) after incubation with $\mathrm{ZnPc}$ photosensitizers $\left(\bullet \mathrm{ZnPc}-(\mathrm{Lys})_{5}\right.$, $\left.\circ \mathrm{ZnPc}-\mathrm{S}_{2} \mathrm{P}_{2}, \boldsymbol{\nabla} \mathrm{ZnPc}-\mathrm{S}_{4}\right)$ : a) $\mathrm{K} 562$ cells, $2 \mathrm{~h}$ incubation; b) K562 cells, $24 \mathrm{~h}$ incubation; c) HELF cells, $2 \mathrm{~h}$ incubation. Data represent the mean \pm SEM of three independent experiments, each performed in triplicate. 


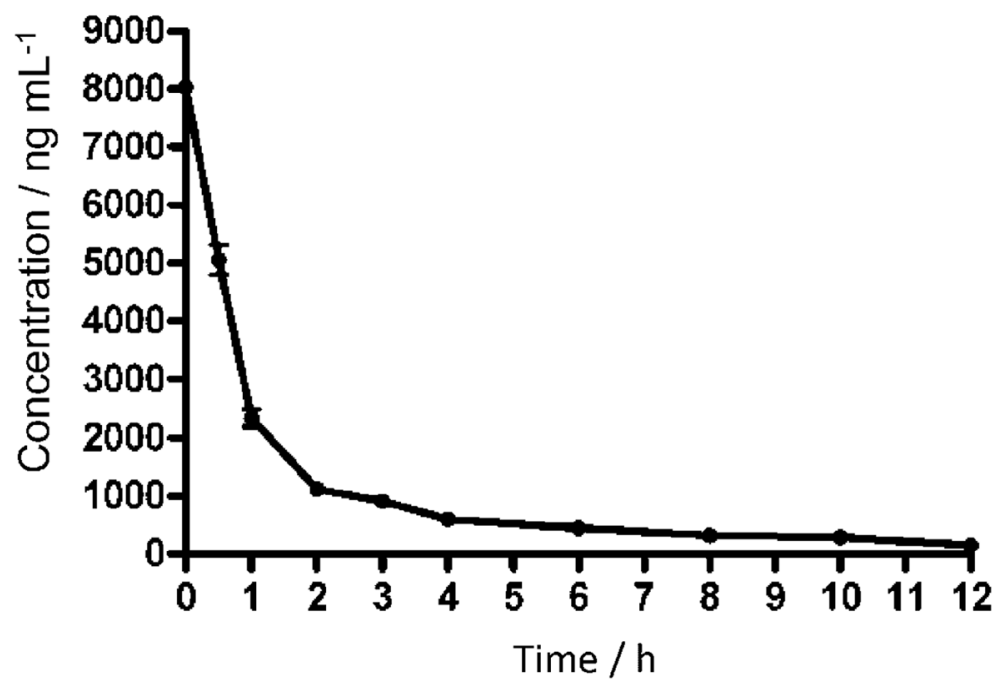

Figure 4.

Plasma concentration of $\mathrm{ZnPc}-(\mathrm{Lys})_{5}\left(2 \mathrm{mg} \mathrm{kg}^{-1}\right.$ i.v.) as a function of time in $\mathrm{S} 180$ tumorbearing mice. 


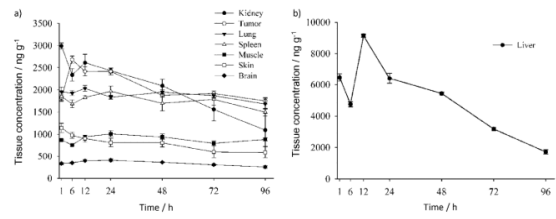

Figure 5.

Tissue concentrations (mean \pm SEM) of ZnPc-(Lys) 5 as a function of time after i.v. injection $\left(2 \mathrm{mg} \mathrm{kg}^{-1}\right)$ in S180 tumor-bearing mice $(n=5)$. 


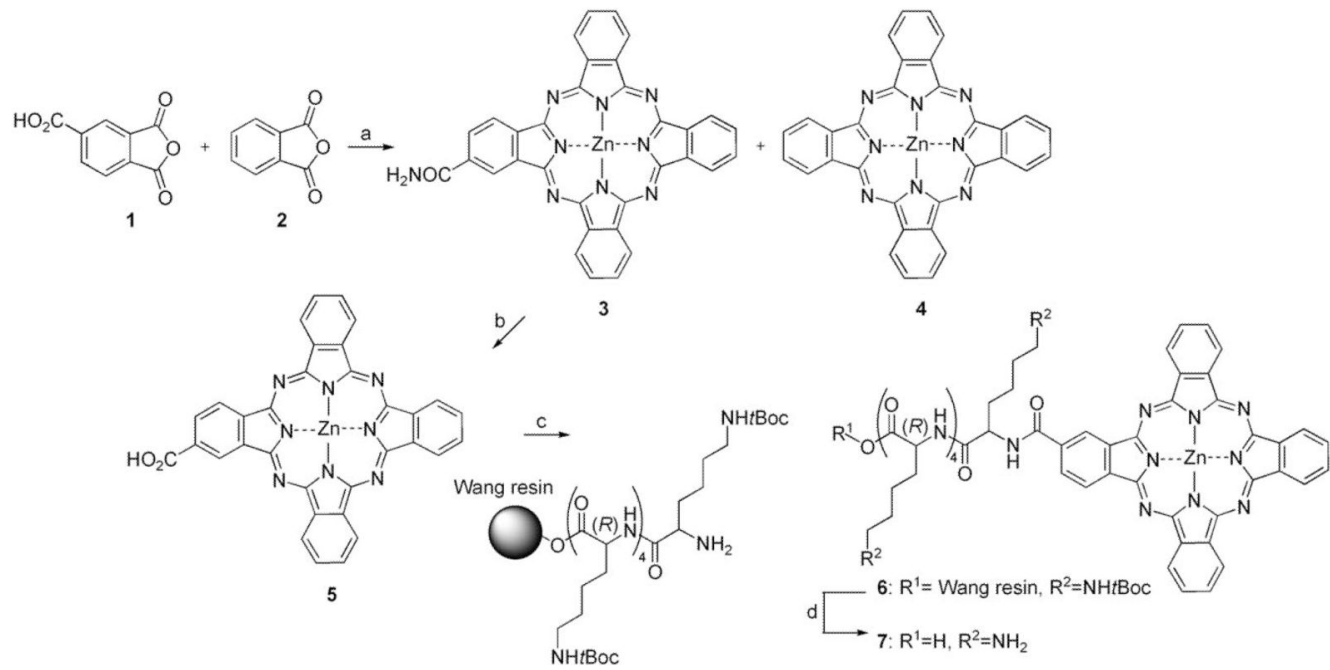

Scheme 1.

Synthesis of pentalysine $\beta$-carbonylphthalocyanine zinc (7, ZnPc-(Lys) 5 ) from the previously described monosubstituted $\beta$-carboxyphthalocyanine zinc (5, ZnPc-COOH).[20] Complex 5 was purified on a self-packed silica gel column. Reagents and conditions: a) $\left(\mathrm{NH}_{2}\right)_{2} \mathrm{CO}, \mathrm{Zn}(\mathrm{OAc})_{2},\left(\mathrm{NH}_{4}\right)_{2} \mathrm{MoO}_{4}, 170{ }^{\circ} \mathrm{C}, 4 \mathrm{~h}$; b) $\mathrm{KOH}(1 \mathrm{M}), 100{ }^{\circ} \mathrm{C}, 24 \mathrm{~h}$; c) DCC, HOBt, $25{ }^{\circ} \mathrm{C}, 24 \mathrm{~h}$; d) TFA $(95 \%), 25^{\circ} \mathrm{C}, 3 \mathrm{~h}$. The final yield of 7 is $33.8 \%$ based on $\mathbf{5}$ ( $\mathrm{ZnPc}-\mathrm{COOH})$. 
Table 1

Antitumor activity of ZnPc-(Lys) 5 against an S180 tumor model implanted in Kunming mice. ${ }^{[a]}$

\begin{tabular}{|lcccc|}
\hline PDT Treatment & \multicolumn{2}{c}{ Body weight [g] } & Tumor weight $[\mathrm{g}]$ & Inhibition [\%] \\
& Day 1 & Day 10 & & \\
\hline Vehicle & $30.4 \pm 1.0$ & $35.6 \pm 2.2$ & $2.08 \pm 0.14$ & - \\
$0.5 \mathrm{mgkg}^{-1} \mathrm{ZnPc}-(\mathrm{Lys})_{5}$ & $30.2 \pm 0.9$ & $32.4 \pm 1.9$ & $0.80 \pm 0.10^{*}$ & 61.4 \\
$1 \mathrm{mgkg}^{-1} \mathrm{ZnPc}-(\mathrm{Lys})_{5}$ & $30.3 \pm 0.8$ & $34.1 \pm 2.0$ & $0.28 \pm 0.04^{*}$ & 86.8 \\
$2 \mathrm{mgkg}^{-1} \mathrm{ZnPc}-(\mathrm{Lys})_{5}$ & $31.1 \pm 0.7$ & $32.6 \pm 1.9$ & $0.32 \pm 0.05^{*}$ & 84.4 \\
$2 \mathrm{mgkg}^{-1} \mathrm{ZnPc}-(\mathrm{Lys})_{5}$, dark & $29.6 \pm 0.9$ & $33.2 \pm 1.7$ & $1.08 \pm 0.12^{*}$ & 47.9 \\
Light, no photosensitizer & $30.6 \pm 1.2$ & $35.3 \pm 1.4$ & $1.33 \pm 0.21^{*}$ & 35.9 \\
\hline
\end{tabular}

$[a] 12 \mathrm{~h}$ after injection of the indicated amount of ZnPc-(Lys)5, tumors were illuminated once with laser light $\left(\lambda 670 \mathrm{~nm}, 217 \mathrm{~mW} \mathrm{~cm}^{-2}\right)$ for a total fluence of $65 \mathrm{~J} \mathrm{~cm}^{-2}$. Data represent the mean \pm SEM of $n=7$ experiments in each case, and were analyzed using a one-way ANOVA and Newman-Keuls test;

indicates significant difference (at $p<0.01$ ) from vehicle control. 